\title{
EFEKTIFITAS PEMBELAJARAN BERBASIS INQUIRY UNTUK MENINGKATKAN PENGUASAAN KONSEP DAN KEMAMPUAN BERPIKIR KREATIF MAHASISWA FARMASI PADA MATA KULIAH ANATOMI FISIOLOGI MANUSIA
}

\author{
Rahmawida Putri \\ Sekolah Tinggi Farmasi Muhammadiyah Tangerang \\ rahmawidaputri0@gmail.com
}

\begin{abstract}
ABSTRAK
Penelitian ini bertujuan untuk menguji efektivitas pembelajaran berbasis inquiry untuk meningkatkan penguasaan konsep dan kemampuan berpikir kreatif mahasiswa farmasi muhammadiyah Tangerang. Desain penelitian ini menggunakan metode Quasi Experiment dengan Pretest-Posttest Control Group, Non-Equivalent Control Group Design. Studi ini melibatkan 70 siswa pada semester 2 Sekolah Tinggi Farmasi Muhammadiyah Tangerang dengan pengumpulan data menggunakan wawancara dosen, kuesioner, dan hasil penelitian dianalisis menggunakan uji-t. Hasil penelitian menunjukkan bahwa (1) ada peningkatan penguasaan konsep mahasiswa farmasi Sekolah Tinggi Farmasi Muhammadiyah Tangerang pada Mata Kuliah Anatomi Fisiologi Manusia yang diberikan pembelajaran berbasis inquiry; (2) ada peningkatan kemampuan berpikir kreatif mahasiswa farmasi Sekolah Tinggi Farmasi Muhammadiyah Tangerang pada Mata Kuliah Anatomi Fisiologi Manusia yang diberikan pembelajaran berbasis inquiry.
\end{abstract}

Kata Kunci: Inquiry, Penguasaan Konsep, Berpikir Kreatif

\begin{abstract}
The study aims to test the effectiveness of learning based on inquiry to increase mastery of concepts and creative thinking skill of pharmacy students college of Pharmacy Muhammadiyah Tangerang. Design this research used Quasi Experiment Method with Pretest-Posttest, NonEquivalent Control Group Design. The study involved 70 students in semester 2 college of Pharmacy Muhammadiyah Tangerang which the data was collected by using interview lecturer, questionnaire, the results of the study were analyzed using uji-t. The results show that (1) there is an increase in student mastery of concepts of pharmacy college of Pharmacy Muhammadiyah Tangerang on courses Anatomy Human Physiology given learning inquiry-based; (2) there is an increase in creative thinking skills of pharmacy students college of Pharmacy Muhammadiyah Tangerang on courses Anatomy Human Physiology given learning inquiry-based.
\end{abstract}

Keywords: Inquiry, Mastery of Concepts, Creative Thinking

\section{PENDAHULUAN}

Pembelajaran adalah suatu proses dimana mahasiswa mengembangkan potensi yang dimiliki untuk mendapatkan suatu pengetahuan dan pemahaman. Untuk mencapai tujuan pembelajaran dibutuhkan adanya keterlibatan mahasiswa dengan ketepatan metode pembelajaran yang digunakan oleh dosen. Miarso, Yusufhadi (2004) mengatakan bahwa efektifitas pembelajaran merupakan salah satu standar mutu pendidikan dan seringkali diukur dengan tercapainya tujuan, atau dapat juga diartikan sebagai ketepatan dalam mengelola suatu situasi, "doing the right things". Efektifitas pembelajaran adalah ukuran keberhasilan dari suatu prises interaksi antarmahasiswa dengan dosen dalam situasi eduktif untuk mencapai tujuan pembelajaran. Efektifitas pembelajaran dapat dilihat dari aktivitas mahasiswa selama pembelajaran berlangsung, respon mahasiswa terhadap pembelajaran dan penguasaan konsep mahasiswa. Untuk mencapai suatu konsep pembelajaran yang efektif dan efisien perlu adanya hubungan timbal balik antara mahasiswa dan dosen untuk mencapai suatu tujuan secara bersama. Selain itu juga harus disesuaikan dengan kondisi lingkungan sekolah, sarana dan prasarana, serta media 
pembelajaran yang dibutuhkan untuk membantu tercapainya seluruh aspek perkembangan mahasiswa.

Mata kuliah Anatomi Fisiologi Manusia menekankan mahasiswa harus mengembangkan rasa ingin tahu melalui penemuan/inquiry berdasarkan pengalaman langsung yang dilakukan melalui kerja ilmiah untuk memanfaatkan fakta, membangun konsep, prinsip, teori, dan hukum. Pembelajaran dengan integrasi kegiatan ilmiah pada umumnya merupakan kegiatan inquiry. Menurut Sani (2014) dan Alberta Learning (2004), pembelajaran berbasis inquiry merupakan pembelajaran yang melibatkan mahasiswa dalam merumuskan pertanyaan yang mengarahkan mahasiswa untuk melakukan investigasi dalam upaya membangun pengetahuan dan makna baru. Mata Kuliah Anatomi Fisiologi Manusia merupakan mata kuliah yang pembelajarannya berbasis penemuan sehingga pembelajaran berbasis inquiry merupakan pembelajaran yang sesuai dengan kegiatan pembelajarannya.

Berdasarkan hasil wawancara dengan dosen mata kuliah Anatomi Fisiologi Manusia yang diajarkan pada semester 2 (genap) tahun ajaran 2018/2019 dan observasi kegiatan belajar mengajar memperlihatkan bahwa ada beberapa kendala dalam pembelajaran yang diterapkan. Berdasarkan hasil wawancara, peneliti menemukan masih banyak mahasiswa yang mendapat nilai $<50$ dari nilai minimum \68 yang menjadikan pembelajaran belum mampu tercapai ketuntasan minimum. Salah satu yang menyebabkan rendahnya kemampuan pemahaman konsep dan berpikir kreatif mahasiswa dikarenakan sistem pembelajaran yang masih menggunakan metode ceramah.

Menurut Hamdani (2011) metode ceramah merupakan metode yang berbentuk penjelasan konsep, prinsip, dan fakta yang ditutup dengan tanya jawab oleh dosen dan mahasiswa. Selain itu, saat pembelajaran berlangsung, dari 100\% mahasiswa yang hadir mengikuti perkuliahan
Anatomi Fisiologi Manusia, 70\% sudah aktif namun 30\% mahasiswa pasif dalam mengikuti pembelajaran. Kurangnya keterlibatan mahasiswa dalam pembelajaran dapat berpengaruh terhadap hasil belajar yang diperoleh. Hal ini juga disebabkan dalam proses pembelajaran mahasiswa tidak dilibatkan secara aktif dan dosen cenderung memindahkan pengetahuan yang dimilikinya ke pikiran mahasiswa dengan berbagai macam cara seperti memberitahu, mengajari, melatih, menyelesaikan soal, menyatakan fakta-fakta, mementingkan hasil belajar daripada proses, memberi pujian kepada mahasiswa jika mahasiswa tersebut dapat menjawab dengan benar dan memarahi mahasiswa jika salah menjawab, serta mengajarkan materi secara urut halaman per halaman tanpa menjelaskan keterkaitan antara konsep-konsep atau masalah. Kondisi yang demikian tentunya akan menghambat mahasiswa untuk berpikir kreatif.

Kemampuan berpikir kreatif mahasiswa dalam proses pembelajaran juga dipengaruhi dengan metode pembelajaran yang digunakan oleh dosen dalam kegiatan belajar mengajar. Perkembangan optimal dari kemampuan berpikir kreatif mahasiswa berhubungan erat dengan cara mengajar (Munandar, 2002). Oleh sebab itu, harus dicari solusi yang tepat untuk memberdayakan peningkatan pemahaman mahasiswa terhadap konsep.

Penerapan metode pembelajaran yang mengadopsi metode penelitian para peneliti membantu mahasiswa dalam memahami hasil, tujuan, dan sifat sains karena proses dalam sains juga dipahami mahasiswa (Joyce, dkk. 2009). Salah satu metode pembelajaran yang dapat diterapkan adalah pembelajaran berbasis inquiry atau penemuan. Metode pembelajaran yang digunakan dalam proses pembelajaran sangat mempengaruhi aktivitas dan keterlibatan mahasiswa dalam pembelajaran. Metode pembelajaran yang sesuai diterapkan pada suatu materi pembelajaran akan membuat pembelajaran efektif. 
Pembelajaran inquiry dirancang untuk mengajak mahasiswa secara langsung dalam proses ilmiah dalam waktu singkat. Hasil penelitian Schlenker, dalam Joyce dan Weil, menunjukkan bahwa latihan inquiry dapat meningkatkan kemampuan pemahaman konsep, produktif dalam berpikir kreatif, dan mahasiswa menjadi terampil dalam memperoleh informasi (Trianto, 2007). Metode pembelajaran berbasis inquiry ini cocok untuk diterapkan dalam mata kuliah Anatomi Fisiologi Manusia. Hal ini dikarenakan metode pembelajaran berbasis inquiry lebih menekankan pada keaktifan, pemahaman konsep, serta kemampuan berpikir kreatif mahasiswa. Metode pembelajaran berbasis inquiry ini diharapkan dapat merangsang kemampuan berpikir mahasiswa sehingga dapat mengembangkan kemampuan berpikir kreatif mahasiswa dan dapat meningkatkan pemahaman konsep mahasiswa.

Berdasarkan uraian di atas, terkait metode pembelajaran berbasis inquiry dan efektifitasnya terhadap kemampuan penguasaan konsep dan berpikir kreatif mahasiswa. Oleh karena itu, peneliti berkeinginan untuk melakukan penelitian dengan judul "Efektifitas Pembelajaran Berbasis Inquiry untuk Meningkatkan Pemahaman Konsep dan Kemampuan Berpikir Kreatif Mahasiswa Farmasi pada Mata Kuliah Anatomi Fisiologi Manusia".

\section{METODE}

Penelitian ini dilaksanakan di Sekolah Tinggi Farmasi Muhammadiyah Tangerang. Waktu penelitian dilaksanakan pada bulan Februari sampai dengan Mei 2019. Populasi dalam penelitian ini adalah seluruh mahasiswa farmasi semester 2 (genap) Tahun Ajaran 2018/2019 Sekolah Tinggi Farmasi Muhammadiyah Tangerang yang mengikuti mata kuliah Anatomi Fisiologi Manusia yang berjumlah 70 orang mahasiswa yang terdiri dari 2 kelas yaitu Semester II Kelas A berjumlah 37 mahasiswa dan Semester II Kelas B berjumlah 33 mahasiswa.
Instrumen penelitian yang digunakan untuk menilai kemampuan penguasaan konsep dan kemampuan berpikir kreatif mahasiswa farmasi adalah berupa soal pretest dan posttest. Teknik pengambilan sampel yang dilakukan adalah purposive sampling, dengan desain penelitian sebagai berikut :

\begin{tabular}{lccc}
\multicolumn{4}{c}{ Tabel 1. Desain Penelitian } \\
\hline Kelompok & Pretest & Perlakuan & Posttest \\
\hline Eksperimen & Y1 & X1 & Y2 \\
Kontrol & Y1 & X2 & Y2 \\
\hline \multicolumn{4}{c}{ Keterangan: } \\
Y1 : Tes awal atau Pretest \\
Y2 : Tes akhir atauPossttest \\
X1 : Kelas Eksperimen (Model Pembelajaran \\
Inquiry) \\
X2 : Kelas Kontrol/Konvensional (Model Ceramah)
\end{tabular}

Adapun prosedur dan tahap-tahap penelitian ini adalah sebagai berikut; (1) Tahap persiapan dengan mengumpulkan hasil wawancara, membuat instrument penelitian berupa soal pretest dan posttest, dan mempersiapkan bahan ajar berupa RPKPS Mata Kuliah Anatomi Fisiologi Manusia; (2) Tahap pelaksanaan dengan proses pengajaran Mata Kuliah Anatomi Fisiologi Manusia kepada kelas Eksperimen yang diberikan pembelajaran dengan metode inquiry dan kelas kontrol dengan metode ceramah; (3) Tahap pengumpulan data dengan mengumpulkan hasil pretest dan posttest mahasiswa kelas eksperimen yang diberikan pembelajaran dengan menggunakan metode inquiry dan kelas kontrol dengan menggunakan metode ceramah. Adapun langkah- langkah teknik validasi instrument dalam penelitian sebagai berikut: (1) Uji Validitas Tes; (2) Reliabilitas Tes; (3) Taraf Kesukaran Tes; (4) Daya PembedaTes; (5) Teknik Analisis Data dengan menggunakan program SPSS 22,0 forwindows.

\section{HASIL DAN PEMBAHASAN Kemampuan Awal Mahasiswa (Pretest)}

Hasil analisis kemampuan awal mahasiswa menunjukkan bahwa kemampuan penguasaan konsep dan kemampuan berpikir kreatif mahasiswa tidak ada perbedaan yang signifikan 
Rahmawida Putri, Efektifitas Pembelajaran Berbasis Inquiry Untuk Meningkatkan Penguasaan Konsep Dan Kemampuan Berpikir Kreatif Mahasiswa Farmasi Pada Mata Kuliah Anatomi Fisiologi Manusia

Jurnal Biolokus: Jurnal Penelitian Pendidikan Biologi Dan Biologi Vol.3 (2)

antara kelompok kontrol dan kelompok eksperimen dari hasil skor pretest (Tabel 2).

Hasil analisis tersebut mengindikasikan bahwa mahasiswa yang diberikan pembelajaran berbasis inquiry dan mahasiswa yang diberikan pembelajaran konvensional memiliki kemampuan dan pengetahuan awal penguasaan konsep dan kemampuan berpikir kreatif yang sama. Hasil tersebut ditunjukkan pada Gambar 1 dan Gambar 2.

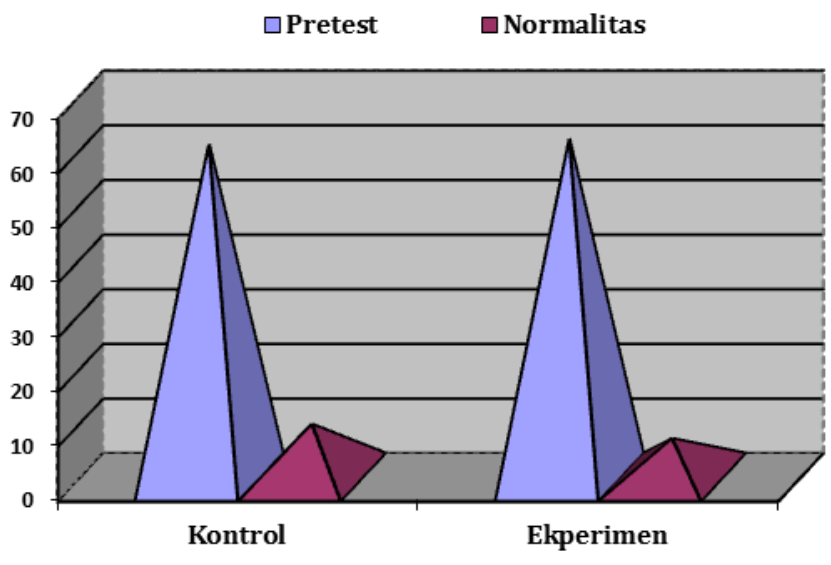

Gambar 1. Perbandingan Penguasaan Konsep Awal Mahasiswa Kelompok Kontrol dan Kelompok Eksperimen.

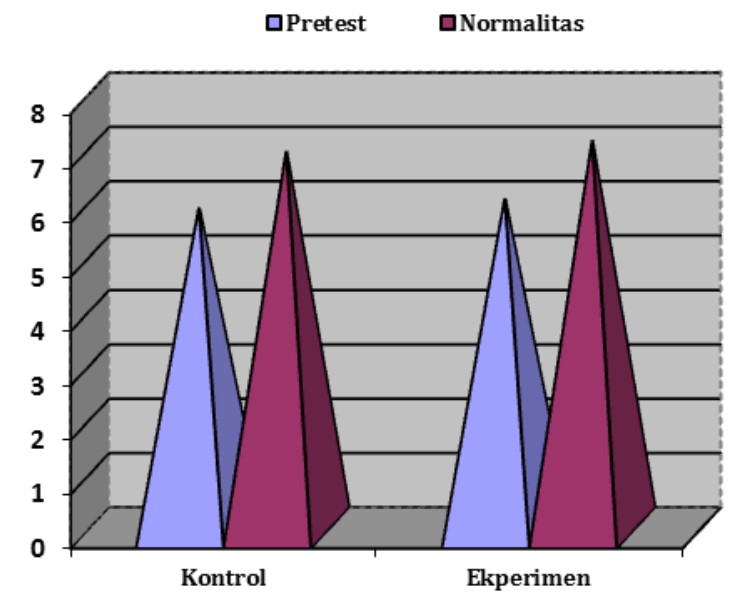

Gambar 2. Perbandingan Kemampuan Berpikir Kreatif Awal Mahasiswa Kelompok Kontrol dan Kelompok Eksperimen

\section{Kemampuan Akhir Mahasiswa (Posttest)}

Hasil analisis kemampuan akhir mahasiswa menunjukkan bahwa kemampuan penguasaan konsep dan kemampuan berpikir kreatif mahasiswa terdapat perbedaan yang signifikan antara kelompok kontrol dan kelompok eksperimen dari hasil posttest (Tabel 3).

Kemampuan mahasiswa setelah pelaksanaan pembelajaran berbasis inquiry diukur melalui posttest untuk melihat ada tidaknya peningkatan kemampuan penguasaan konsep dan kemampuan berpikir kritis.

Tabel 2. Uji Beda Rata-Rata Pretes Penguasaan Konsep dan Kemampuan Berpikir Kreatif Mahasiswa Kelompok Kontrol dan Kelompok Eksperimen.

\begin{tabular}{cccccc}
\hline Rata-Rata & \multicolumn{2}{c}{ Kelompok } & \multicolumn{2}{c}{ Normalitas } & Signifikansi \\
\cline { 2 - 5 } Pretest & Kontrol & Eksperimen & Kontrol & Eksperimen & \\
\hline Penguasaan & 61,00 & 62,00 & Normal & Normal & Tidak Signifikan \\
Konsep & & & $\mathrm{X}^{2}$ hit $<\mathrm{X}^{2}$ tab & $\mathrm{X}^{2}$ hit $<\mathrm{X}^{2}$ tab & thit $_{\text {tabel }}$ \\
& & & $(9,76<11,07)$ & $(10,20<11,07)$ & $(1,615<1,671)$ \\
\hline Kemampuan & 5,90 & 6,07 & Normal & Normal & Tidak Signifikan \\
Berpikir & & & $\mathrm{X}^{2}$ hit $<\mathrm{X}^{2}$ tab & $\mathrm{X}^{2}$ hit $<\mathrm{X}^{2}$ tab & thit $_{\text {tab }}<\mathrm{t}_{\text {tabel }}$ \\
Kreatif & & & $(6,94<11,07)$ & $(7,14<11,07)$ & $(2,515<1,671)$ \\
\hline
\end{tabular}

Tabel 3. Uji Beda Rata-Rata Postest Penguasaan Konsep dan Kemampuan Berpikir Kreatif Mahasiswa Kelompok Kontrol dan Kelompok Eksperimen.

\begin{tabular}{cccccc}
\hline Rata-Rata & \multicolumn{2}{c}{ Kelompok } & \multicolumn{2}{c}{ Normalitas } & Signifikansi \\
\cline { 2 - 5 } Postest & Kontrol & Eksperimen & Kontrol & Eksperimen & \\
\hline Penguasaan & 75,00 & 80,00 & Normal & Normal & Signifikan \\
Konsep & & & $\mathrm{X}^{2}$ hit $<\mathrm{X}^{2}$ tab & $\mathrm{X}^{2}$ hit $<\mathrm{X}^{2}$ tab & thit $>$ tabel \\
& & & $(10,16<11,07)$ & $(11,50<11,07)$ & $(1,776>1,671)$ \\
\hline Kemampuan & 11,50 & 14,50 & Normal & Normal & Signifikan \\
Berpikir & & & $\mathrm{X}^{2}$ hit $<\mathrm{X}^{2}$ tab & $\mathrm{X}^{2}$ hit $<\mathrm{X}^{2}$ tab & thit $_{\text {tabel }}$ \\
Kreatif & & & $(7,89<11,07)$ & $(8,10<11,07)$ & $(3,464>1,671)$ \\
\hline
\end{tabular}




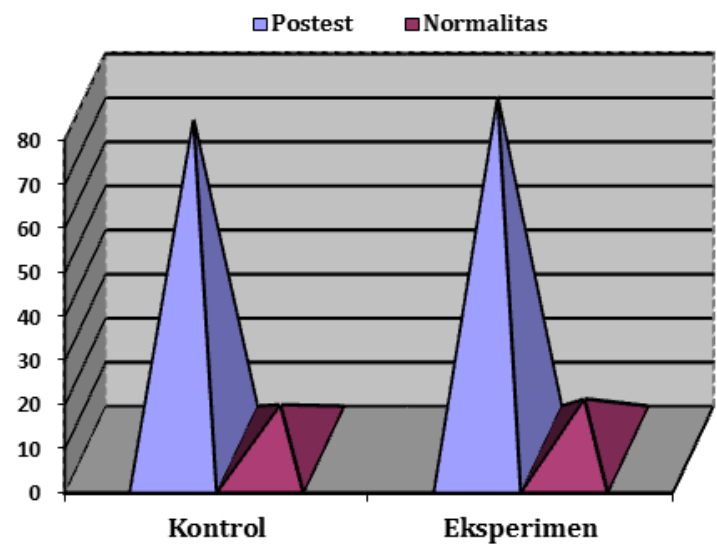

Gambar 3. Perbandingan Penguasaan Konsep Akhir Mahasiswa Kelompok Kontrol dan Kelompok Eksperimen.

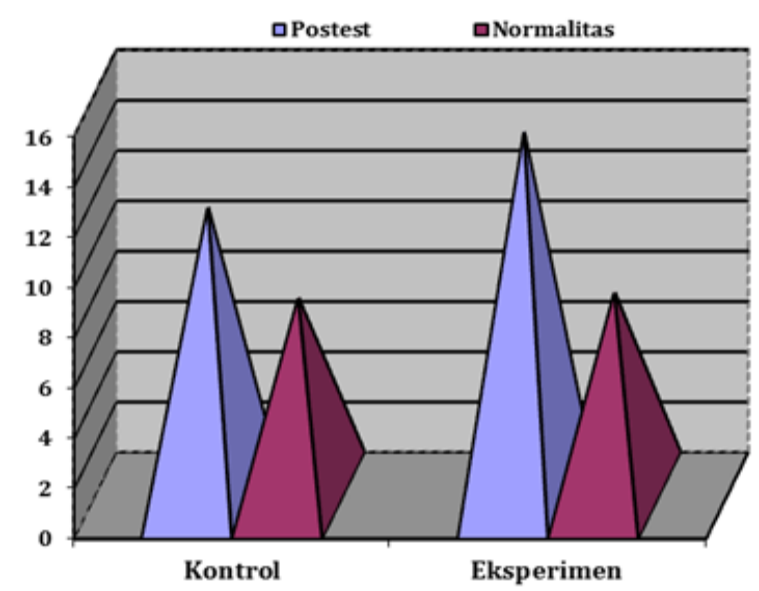

Gambar 4. Perbandingan Kemampuan Berpikir Kreatif Akhir Mahasiswa Kelompok Kontrol dan Kelompok Eksperimen.

\section{Penguasaan Konsep Mahasiswa}

Data penguasaan konsep awal antara kelompok eksperimen dan kelompok kontrol menunjukkan adanya peningkatan nilai homogenitas dengan selisih rata-rata skor pretest dan posttest mencapai 0,06. Nilai signifikansi dengan selisih rata-rata skor pretest dan posttest mencapai 0,161 (Gambar 5).

Hasil Uji-t terhadap penguasaan konsep mahasiswa kelompok kontrol dan kelompok eksperimen terdapat perbedaan yang signifikan rata-rata penguasaan konsep mahasiswa antara kelompok kontrol dan kelompok eksperimen pada taraf kepercayaan 95\% menunjukkan bahwa $\mathrm{Ha}$ Diterima (rata-rata penguasaan konsep mahasiswa kelas eksperimen lebih besar daripada kelas kontrol).

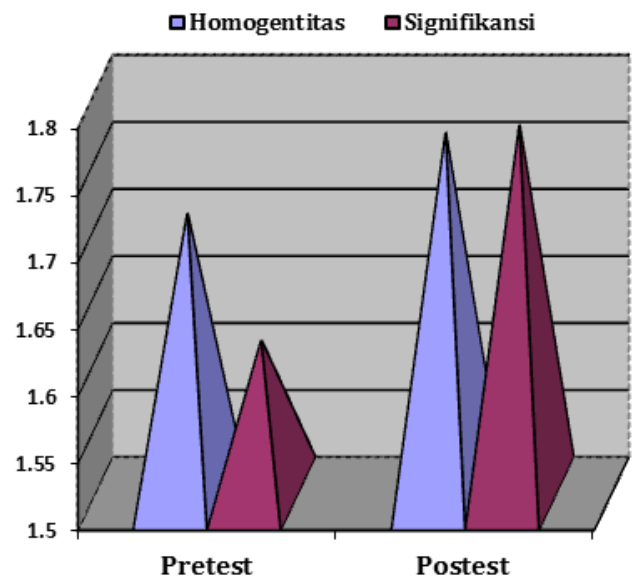

Gambar 5. Perbandingan Penguasaan Konsep Mahasiswa.

Hasil ini sejalan dengan penelitian yang telah dilakukan oleh Aini, Z., Ramdani, A., \& Raksun, A. 2018, dari analisis penguasaan konsep siswa menunjukkan bahwa siswa yang mengikuti pembelajaran dengan menggunakan model pembelajaran guided inquiry memiliki nilai rata-rata sebesar 69,52 dari nilai rata-rata awal hasil belajar sebesar 38,10. Sehingga penggunaan model pembelajaran guided inquiry dapat meningkatkan penguasaan konsep siswa. Kegiatan penelitian yang dilakukan oleh Suwandari, P. K., Taufik, M., \& Rahayu, S. 2018 juga menjelaskan hal yang sama bahwa dari hasil penelitiannya penggunaan model pembelajaran inquiry terbimbing dapat meningkatkan hasil penguasaan konsep siswa. Hal ini dapat dilihat dari hasil perhitungan skor rata-rata siswa pada kelas eksperimen yang diajarkan dengan menggunakan model pembelajaran inquiry terbimbing sebesar 134, sedangkan skor ratarata siswa pada kelas kontrol yang diajarkan dengan menggunakan model pembelajaran konvensional sebesar 114 .

\section{Kemampuan Berpikir Kreatif}

Data kemampuan berpikir kreatif antara kelompok eksperimen dan kelompok kontrol menunjukkan adanya peningkatan nilai homogenitas dengan selisih rata-rata skor pretest dan posttest mencapai 0,04. Nilai signifikansi dengan selisih rata-rata skor pretest dan posttest mencapai 0,949 (Gambar 6). 


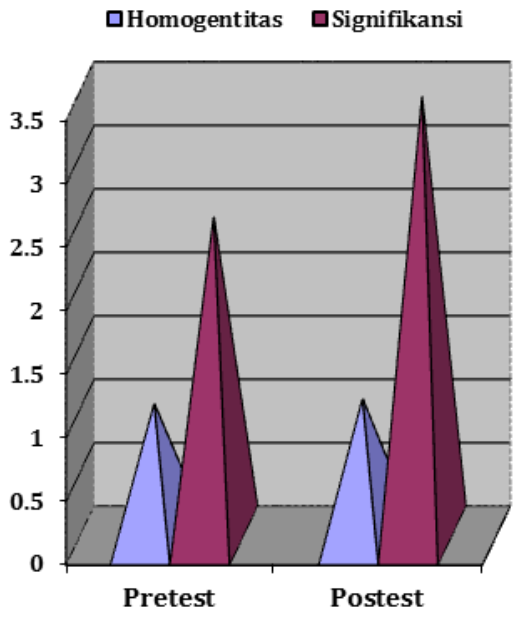

Gambar 6. Perbandingan Kemampuan Berpikir Kreatif Mahasiswa.

Hasil Uji-t terhadap kemampuan berpikir kreatif mahasiswa kelompok kontrol dan kelompok eksperimen terdapat perbedaan yang signifikan rata-rata kemampuan berpikir kreatif mahasiswa antara kelompok kontrol dan kelompok eksperimen pada taraf kepercayaan 95\% menunjukkan bahwa Ha Diterima (ratarata penguasaan konsep mahasiswa kelas eksperimen lebih besar daripada kelas kontrol).

Hasil penelitian yang telah dilakukan oleh peneliti sejalan dengan hasil penelitian yang telah dilakukan oleh Setiawan, H., Setiany, E. P., Andiarani, M., \& Hidayat, W. 2018, bahwa nilai yang diperoleh siswa setelah di analisis dengan menggunakan non parametric Man Whitney- $U$ pada Monte Carlo Sig. diperoleh signifikansi berpikir kreatif sebesar 0,361 >0,05. Maka dari hasil tersebut menyatakan bahwa pencapaian kemampuan berpikir kreatif siswa yang menggunakan model pembelajaran Inquiry Guided lebih baik dibandingkan dengan pencapaian kemampuan berpikir kreatif siswa yang menggunakan model pembelajaran konvensional. Hasil penelitian tersebut diperkuat dengan hasil penelitian yang telah dilakukan oleh Ulandari, N., Putri, R., Ningsih, F., \& Putra, A. 2019, yang mendapatkan hasil bahwa perolehan rata-rata skor kemampuan berpikir kreatif siswa yang menggunakan model pembelajaran inquiry sebesar 2,00 dibandingkan dengan rata-rata skor kemampuan berpikir kreatif siswa yang menggunakan model pembelajaran konvensional sebesar 1,40 dengan hasil $t_{\text {hitung }}$ 3,0048 $>t_{\text {tabel }} 2,0021$. Dari hasil ini menunjukkan bahwa model pembelajaran inquiry berpengaruh terhadap kemampuan berpikir kreatif siswa.

Model pembelajaran inquiry dapat dijadikan model pembelajaran yang dapat meningkatkan kemampuan penguasaan konsep dan kemampuan berpikir kreatif peserta didik. Hal ini dikarenakan model pembelajaran inquiry dapat melatih peserta didik untuk bernalar dan berpikir serta memahasi suatu konsep pembelajaran serta berusaha memberikan kebenaran dari suatu permasalahan. Sehingga model pembelajaran inquiry sangat memberikan efektifitas terhadap hasil penguasan konsep dan kemampuan berpikir kreatif mahasiswa farmasi dalam memahami dan mempelajari mata kuliah Anatomi Fisiologi Manusia.

\section{PENUTUP}

Dari hasil analisis data yang telah dilakukan didapatkan bahwa nilai signifikansi hasil pretest $t_{\text {hitung }} 1,615>t_{\text {tabel }} 1,671$ untuk kemampuan penguasaan konsep mahasiswa dan nilai signifikansi hasil posttest $t_{\text {hitung } 1,776>t_{\text {tabel }}} 1,671$ untuk kemampuan penguasaan konsep mahasiswa.Dan nilai signifikansi hasil pretest $t_{\text {hitung }} 2,515>t_{\text {tabel }} 1,671$ untuk kemampuan berpikir kreatif mahasiswa dan nilai signifikansi hasil posttest $t_{\text {hitung }} 3,464>t_{\text {tabel }} \quad 1,671$ untuk kemampuan berpikir kreatif mahasiswa. Berdasarkan analisis data dan pembahasan hasil penelitian dapat dirumuskan kesimpulan sebagai berikut. (1) terdapat peningkatan penguasaan konsep mahasiswa farmasi Sekolah Tinggi Farmasi Muhammadiyah Tangerang pada mata kuliah Anatomi Fisiologi Manusia yang diberikan pembelajaran berbasis inquiry sebesar 0,161, (2) terdapat peningkatan kemampuan berpikir kreatif mahasiswa farmasi Sekolah Tinggi Farmasi Muhammadiyah Tangerang pada mata kuliah Anatomi Fisiologi Manusia yang diberikan pembelajaran berbasis inquiry sebesar 0.949 . 
Rahmawida Putri, Efektifitas Pembelajaran Berbasis Inquiry Untuk Meningkatkan Penguasaan Konsep Dan Kemampuan Berpikir Kreatif Mahasiswa Farmasi Pada Mata Kuliah Anatomi Fisiologi Manusia Jurnal Biolokus: Jurnal Penelitian Pendidikan Biologi Dan Biologi Vol.3 (2)

\section{REFERENSI}

Aini, Z., Ramdani, A., \&Raksun, A. (2018). Perbedaan Penguasaan Konsep Biologi Dan Kemampuan Berpikir Kritis Siswa Kelas X Pada Penerapan Model Pembelajaran Kooperatif Tipe Group Investigation Dan Guided Inquiry di MAN 1 Praya. Jurnal Pijar Mipa, 13(1), 19-23.

Febrianti, Y., Djahir, Y., Fatimah, S. (2016). Analisis Kemampuan Berpikir Kreatif Peserta Didik. Jurnal Profit, 3(1), 121-127.

Hamdani. (2011). Strategi Belajar Mengajar. Bandung: Pustaka Setia.

Hamdani, D.. E. Kurniati \&Sakti. (2012). Pengaruh Model Pembelajaran Generatif dengan Menggunakan Alat Peraga terhadap Pemahaman Konsep Cahaya kelas VII di SMP Negeri 7 Kota Bengkulu. Jurnal Exacta, 10 (1), $79-88$.

Joyce, B., M. Weil \& E. Calhoun. (2009). Models of Teaching: Model-Model Pengajaran (8thed). Translated by Fawaid A \& A. Mirza 2009.

Lestari, N. D. (2018). Pembelajaran Autentik dalam Menulis Teks Deskripsi. Jurnal Efektor, 5 (2), 74-85.

Miarso, Y. (2004). Menyemai Benih Teknologi Pendidikan. Jakarta: Kencana.

Munandar, U. (2002). Kreativitas dan Keberbakatan. Jakarta: Gramedia.

Sani, R. A. (2014). Pembelajaran Saintifik untuk Implementasi Kurikulum 2013. Jakarta: Bumi Aksara.

Setiawan, D. \& I.G.P.A. Buditjahjanto. (2013). Pengaruh Metode Pembelajaran Inkuiri terhadap Ketuntasan Hasil Belajar Siswa di SMK N Bunduran Sidoarjo. Jurnal Pendidikan Teknik Elektro, 2(1), 301-309.

Setiawan, H., Setiany, E. P., Andiarani, M., \& Hidayat, W. (2018). Meningkatkan Kemampuan Berpikir Kreatif Matematik Siswa Sekolah Menengah Kejuruan Melalui Model Pembelajaran Inquiry Guided. Jurnal Pendidikan Tambusai, 2(3), 1739-1745.
Sugiyono. (2012). Metode Penelitian Kuantitatif, Kualitatif, dan $R \& D$. Bandung: Alfabeta.

Sungkawan, R. M. (2013). Analisis Penguasaan Konsep Awal Fisika pada Pembelajaran Menggunakan Model Advance Organizer Berbasis Eksperimen terhadap Hasil Belajar Fisika. Jurnal Pendidikan Fisika, 2(2), 73-80.

Suwandari, P. K., Taufik, M., \& Rahayu, S. (2018). Pengaruh model pembelajaran inkuiri terbimbing terhadap penguasaan konsep dan keterampilan proses sains fisika peserta didik kelas XI MAN 2 Mataram tahun pelajaran 2017/2018. Jurnal Pendidikan Fisika dan Teknologi, 4(1), 82-89.

Trianggono, M. M. (2017). Analisis Kausalitas Pemahaman Konsep dengan Kemampuan Berpikir Kreatif Siswa pada Pemecahan Masalah Fisika. Jurnal Pendidikan Fisika dan Keilmuan (JPFK), 3(1), 1-12.

Trianto. (2007). Model Pembelajaran Terpadu dalam Teori dan Praktek. Jakarta: Prestasi Pustaka Publisher.

Ulandari, N., Putri, R., Ningsih, F., \& Putra, A. (2019). Efektivitas Model Pembelajaran Inquiry terhadap Kemampuan Berpikir Kreatif Siswa pada Materi Teorema Pythagoras. Jurnal Cendekia: Jurnal Pendidikan Matematika, 3(2), 227-237. 